Pirjo H. Manninen MD FRCPC, Arthur M. Lam MD FRCPC, Adrian W. Gelb MBCH B FRCPC

\title{
Electrocardiographic changes during and after isoflurane-induced hypotension for neurovascular surgery
}

We evaluated the effects of isofurane anaesthesia and induced hypotention in 33 neurosurgical parients by electrocardiographic monitoring and serial cardiac entzyme measirements. An electrocardiogram (ECG) and serum enzymes were abtained preoperarively, introoperarively and pastoperatively in the recovery room and for three consecutive days. ECG leads II, $V_{1}$ and $V_{5}$ were monitored continuously during anaesthesia. Patients who had had a subarachnoid haemorrhage had a high incidence of abnormal preoperative ECG (42 per cent). Ten patients developed ECG changes intraoperatively, but these changes were unrelated to isofurane-induced hypotension. Fifty-three per cent of patients developed an abnormal postoperative ECG. These abnormalities consisted mostly of nonspecific ST segment or $T$ wave changes. At ro time was there an elevarion in cardiac enzyme activity. We found that nonspecific ECG changes are relatively common in patients undergoing vascular neurosurgical procedures. There was no enzymatic evidence of myocardial infarction and we can only speculate that these ECG changes are related to intracranial surgical manipulation.

Key words

ANAESTHETICS, VOLATILE: isoflurane; BRAIN: subarachnoid haemorrhage; HEART: myocardial ischaemia, electrocardiographic abnormalities.

From the Department of Anaesthesia, University Hospital, University of Western Ontario, London, Ontario.

Address correspondence to: Dr. P.H. Manninen, Department of Anacsthesia, P.O. Box 5339, Station "A," London, Ontaria N6A 5 A5.
Electrocardiographic changes simulating myocardial ischaemia frequently occur in patients following a subarachnoid haemorrhage (SAH). ${ }^{1}$ The presence of these abnormalities preoperatively may present a diagnostic dilemma and complicate the anaesthetic management. The purpose of this study was to investigate the additional effects of isoflurane anaesthesia and induced hypotension on the electrocardiogram (ECG) and on cardiac enzymes in neurosurgical patients.

\section{Methods}

This study was approved by the Hcalth Sciences Standing Committee of Human Research of the University of Western Ontario. Informed consent was obtaincd from each patient. Thirty-three patients scheduled for surgery requiring induced hypotension were studied, 27 with cerebral aneurysms and six with arteriovenous malformations (AVM).

All patients were unpremedicated. Anaesthesia was induced with fentanyl $\left(2-3 \mu \mathrm{g} \cdot \mathrm{kg}^{-1}\right)$, thiopentone $(5-6$ $\mathrm{mg} \cdot \mathrm{kg}^{-1}$ ), lidocaine ( $\mathrm{mg} \cdot \mathrm{kg}^{-1}$ ), and succinylcholine ( $1 \mathrm{mg} \cdot \mathrm{kg}^{-1}$ ). Blood pressure and heart rate were continuously monitored and maintained below preoperative levels by the addition of isoflurane or fentanyl during the induction of anaesthesia. Anaesthesia was maintained with nitrous oxide ( 50 per cent), oxygen ( 50 per cent), pancuronium, intermittent fentanyl (maximum 250 $\mu \mathrm{g}$ ) and isofluranc. Monitors included a standard lead-II ECG, intraarterial catheter, central venous catheter or pulmonary artery catheter, nasopharyngeal temperature probe, urinary catheter and end-tidal capnometer. A lumbar subarachnoid catheter was inserted for cerebrospinal fluid drainage. The blood pressure transducer was placed at mid-cephalic level. Patients were ventilated to maintain a $\mathrm{PaCO}_{2}$ of $30-35 \mathrm{mmHg}$. Mannitol (1 gm $\mathrm{kg}^{-1}$ ) was administered intravenously to all patients. Hypotension was induced during dissection and clipping of the cerebral aneurysm and during excision of the AVM. This was accomplished by increasing the inspired isoflurane concentration to 3-4 per cent until the desired level of 
blood pressure was achieved and then gradually decreasing the concentration to a maintenance level $(1.5-2.5$ per cent). When hypotension was no longer required, the inspired concentration was reduced or discontinued until the blood pressure returned to pre-hypotensive levels. On emergence, should hypertension (increase $>30$ per cent of awake systolic pressure) occur treatment with intravenous hydralazine was initiated and propranolol was given if deemed necessary.

A standard 12 lead ECG was obtained preoperatively as well as in the recovery room and each morning for three consecutive postoperative days. Intraoperatively, in addition to lead II, a continuous tape (Holter) monitor of modified chest leads $V_{1}$ and $V_{5}$ was recorded for the duration of anaesthesia. The Holter tape was analyzed postoperatively. All ECG tracings were analyzed by a cardiologist blinded to the events of the operation.

Cardiac enzyme measurements included serum creatine phosphokinase (CPK), serum lactate dehydrogenase $(\mathrm{LDH})$ and their isoenzymes. Blood samples were collected preoperatively, after 20 minutes of hypotension, postoperatively in the recovery room, on day one (the first 24 hours following surgery) every six hours, on day two every 12 hours and once on day three. The postoperative timing of enzyme measurement was chosen to correspond with the diagnostic evaluation used in the assessment of a patient with chest pain. ${ }^{2}$

Statistical analysis was performed using analysis of variance for repeated measures. Where significant difference was found, Dunnett's test was used to assess difference from preoperative values. $\mathrm{P}<0.05$ was considered significant.

\section{Results}

There were no anaesthetic complications during this study. The mean age of the 33 patients was 49 years (range 19-70 years) with 24 females and nine males. Sixteen patients had a preoperative history of hypertension and of these, three had clinical or electrocardiographic evidence of ischaemic heart disease. The remainder had no documented cardiovascular disease. The duration of hypotension was $67 \pm 78$ minutes (mean \pm SD) for the whole group, with $43 \pm 27$ minutes for aneurysms and $173 \pm 136$ minutes for AVM. The mean blood pressure during hypotension was $49 \pm 6 \mathrm{mmHg}$ (aneurysms $48 \pm 6$ $\mathrm{mmHg}$, AVM $54 \pm 6 \mathrm{mmHg}$ ).

Nineteen patients had had a documented SAH prior to surgery and eight of these ( 42 per cent) had an abnormal preoperative ECG (Table). The time interval (mean \pm SD) between the SAH and surgery was $17 \pm 12$ days. The abnormalities included ST segment changes (one patient), nonspecific $T$ wave changes (seven), axis deviation (left two, right one) and arrhythmias (bradycardia - one, tachycardia - two, ventricular extrasystoles - one). The three patients with intact aneurysms and an abnormal preoperative ECG had cardiovascular disease. Four of the six patients with an AVM had had a bleed from 13 days to one year prior to surgery (mean $\pm S D=162 \pm 128$ days), but all had normal preoperative ECG's.

Ten patients had ECG changes on the Holter tape. In eight patients these changes (ST segment - four, T wave three, ventricular extrasystoles - three, intermittent bundle branch block - one) were evident early during the surgical procedure before induced hypotension, and persisted into the recovery room (Figure 1 ). In the other two, changes (flat $\mathrm{T}$ wave) developed towards the end of the surgical procedure at normal blood pressure, but their ECG's in the recovery room were normal. There was no evidence in any patient of ST segment depression occurring only during isoflurane-induced hypotension.

In the recovery room 17 patients developed an abnormal ECG, with marked changes from their preoperative tracing (Table and Figure 2). These included changes in ST segment (five patients), T wave (11), prolonged QT interval (one) and arrhythmias (four). There was a dramatic increase in the total CPK in the immediate postoperative period. However, this was completely due to $\mathrm{CPK}_{3}$ (skeletal muscle) and at no time was there any evidence of detectable $\mathrm{CPK}_{2}$ (cardiac) or $\mathrm{CPK}_{1}$ (brain) (Figure 3). Similarly there was no increase in the $\mathrm{LDH}$ cardiac isoenzymes $\left(\mathrm{LDH}_{1}, \mathrm{LDH}_{2}\right)$ or of the $\mathrm{LDH}_{1} / \mathrm{LDH}_{2}$ ratio (Figure 4). Serum electrolyte measurements made preoperatively and postoperatively were within nomal limits in all patients.

\section{Discussion}

Electrocardiographic changes associated with SAH may

TABLE Electrocardiographic results

\begin{tabular}{|c|c|c|c|c|}
\hline \multirow[b]{2}{*}{ Patients } & \multicolumn{2}{|c|}{$\begin{array}{l}\text { Preoperarive ECG } \\
(n=33)\end{array}$} & \multirow{2}{*}{$\begin{array}{l}\text { Intraoperative } \\
\text { ECG changes } \\
(n=30)\end{array}$} & \multirow{2}{*}{$\begin{array}{l}\text { Posioperative } \\
\text { abnornal ECG } \\
(n=32)\end{array}$} \\
\hline & Normal & Abnormal & & \\
\hline Anetrysm & & & & \\
\hline $\begin{array}{l}\text { Intact } \\
(n=8)\end{array}$ & 5 & $3^{*}$ & 2 & 1 \\
\hline $\begin{array}{l}\text { SAH } \\
(n=19)\end{array}$ & 11 & 8 & 6 & 13 \\
\hline $\begin{array}{l}\text { AVM } \\
\text { Intact } \\
(\mathrm{n}=2)\end{array}$ & 2 & & & 1 \\
\hline $\begin{array}{l}\text { SAH } \\
(n=4)\end{array}$ & 4 & & 2 & 2 \\
\hline
\end{tabular}

* Cardiovascular disease. 

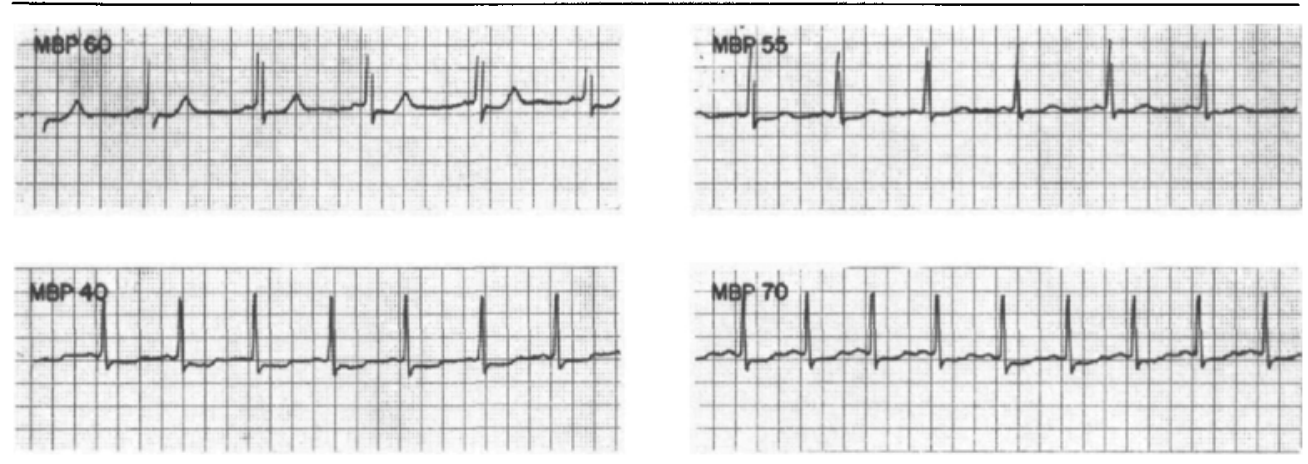

FIGURE 1 Recording of intraoperative Holter monitoring $\left(V_{5}\right)$ in a 57 -year-old hypertensive male 29 days after SAH from a basilar aneurysm. Tracing strips shown were obtained during surgery (mean blood pressure 60 and $55 \mathrm{mmHg}$ ), induced hypotension ( $40 \mathrm{mmHg}$ ) and post-hypotension (70 $\mathrm{mmHg}$ ). Prcoperative ECG was abnormal with nondiagnostic anterior $\mathrm{T}$ wave changes, Postoperative ECG showed inferior and lateral wall $\mathrm{T}$ wave changes.

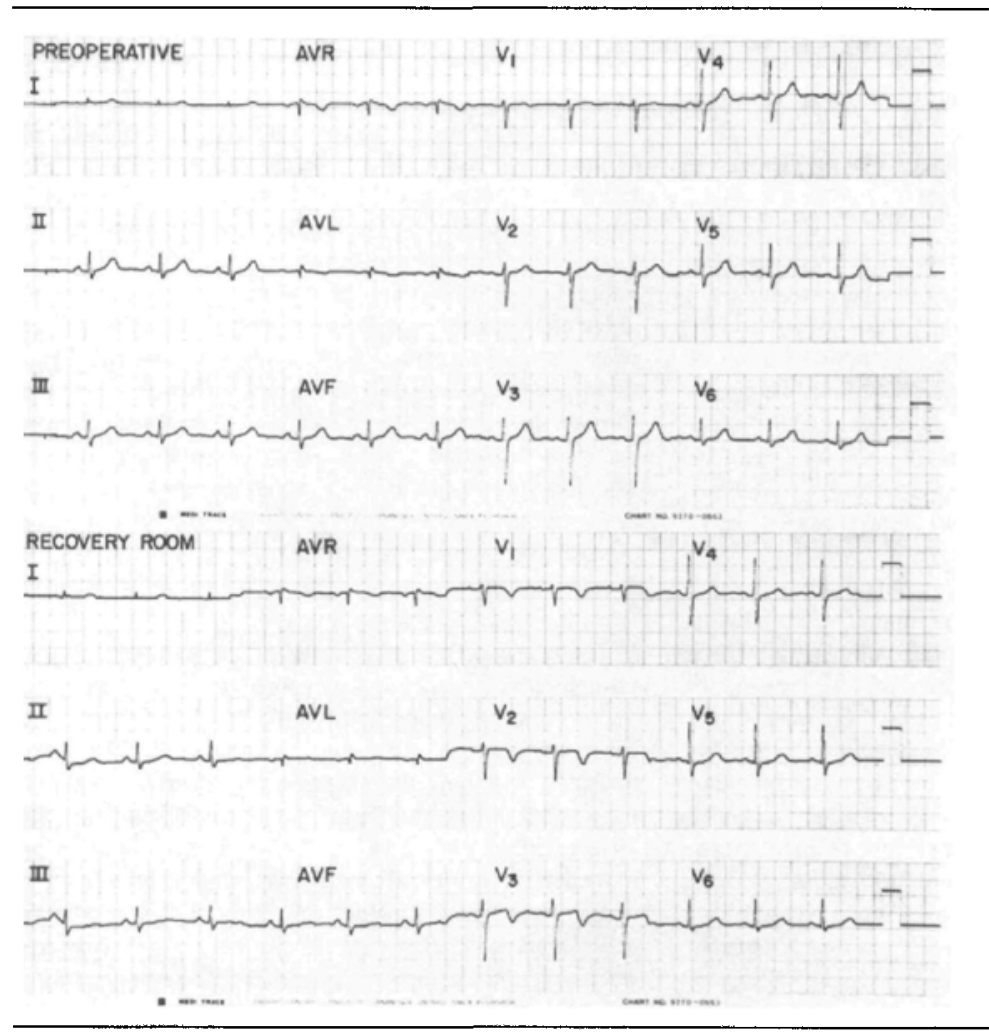

FIGURE 2 ECG from a 57-year-old female previously well who underwent successful clipping of a basilar aneurysm seven days after a SAH. Prcoperative ECG was normal. ECG in recovery room showed changes suggestive of anterior ischaemia. There was no increase in cardiac enzyme activity. 


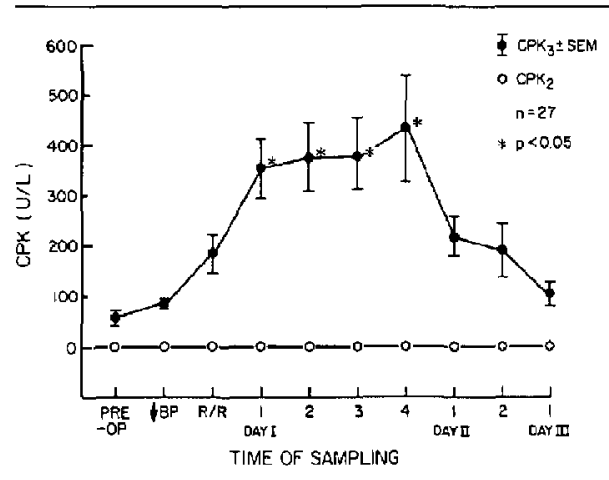

FIGURE 3 Serum $\mathrm{CPK}_{2}$ (cardiac isoenzyme) and serum $\mathrm{CPK}_{3}$ (skeletal muscle isoenzyme) in $u \cdot L^{-1}$ as measured at each time of sampling for patients with cerebral aneuryms $(n=27)$. Mean value $\pm S E M$.

resemble myocardial ischaemia. An abnormal preoperative ECG or new ECG changes during anacsthesia presents the anacsthetist with a dilemma. The question whether the patient should undergo anaesthesia and surgery without full cardiac investigation to rule out a recent myocardial infarction has been raised. ${ }^{3,4}$ In this study, we looked for myocardial ischaemia by using serial ECG's and serum cardiac enzymes in a pattern similar to that used for the investigation and documentation of myocardial infarction, with the assumption that true ischaemic changes may be aggravated during the period of induced hypotension. We found frequent ECG changes intraoperatively and postoperatively, but we found no characteristic serial ECG changes, nor did we find any increase in cardiac isoenzymes to suggest perioperative myocardial infarction.

In our study 42 per cent of the patients with a recent SAH had an abnormal ECG prcoperatively. This is consistent with many previous obscrvations. ${ }^{1.5 .6}$ These ECG abnormalities usually consist of ST segment or nonspecific $T$ wave changes, a prolonged $Q T$ interval and arthythmias. ${ }^{7}$ They may occur immediately after the SAH or may be delayed and are present for a variable period of time, often reverting to normal. ${ }^{8}$ The aetiology has been widely speculated upon but not clearly defined. Some causes suggested include autonomic dysfunction, a rise in catecholamines or an increase in intracranial pressure. 9,10

The interesting finding in our study was that 30 per cent of the patients developed similar ECG changes intraoperatively, unrelated to induced hypotension and a larger percentage ( 53 per cent) occurred postoperatively. These changes varied in the ECG lead location, time of

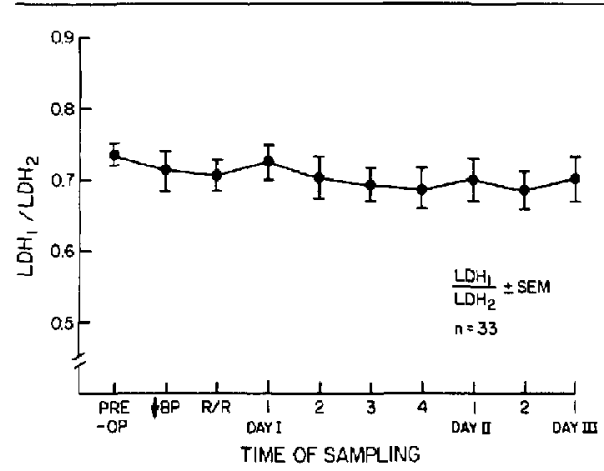

FIGURE 4 Serum $\mathrm{LDH}_{1} / \mathrm{LDH}_{2}$ ratio as measured at each time of sampling for alI patients $(n=33)$. Mean value \pm SEM.

occurrence, duration and occurred in patients with cerebral aneurysms as well as AVM.

Previous investigators have examined the correlation of cardiac enzymes to ECG changes following SAH. The results are conflicting. In earlier studies there was a reported increase, but the cardiac isoenzymes were not identified. ${ }^{8,11}$ In a review of 16 patients with $\mathrm{SAH}$, Fabinyi reported an elevation of cardiac isoenzymes in seven patients, of whom five had abnormal ECG's. ${ }^{12}$ Five other patients had abnormal ECG's without enzyme elevation. Kaste also showed a significant association between cardiac enzyme activity and ECG abnormalities, though his study included various acute cerebral disorders. ${ }^{13}$ Rudehill was unable to confirm this relationship; ${ }^{14}$ in 20 $S A H$ patients with abnormal ECG, he found no elevation of cardiac enzymes. We found no increase in the cardiac isoenzymes intraoperatively or postoperatively to correlatc with the ECG abnormalities.

The cause of the ECG changes intraoperatively and postoperatively can only be speculated upon. Surgical manipulation of the circle of Willis has been reported to cause arrhythmias and $T$ wave changes. ${ }^{15,16} \mathrm{We}$ were unable to correlate the changes we observed to direct manipulations of the brain as in most patients the intraoperative changes were only identified on Holter tape retrospectively. In addition to this, other variables that may influence ECG changes cannot be ruled out; posture and positional changes of the patient, which happens frequently during surgery, can affect ST segment and T wave recording. ${ }^{17}$ In a pilot study evaluating the usefulness of continuous ECG (Holter) monitoring in the perioperative period, Griffin et al. reported that arrhythmias, 
ST segment and $\mathrm{T}$ wave changes occurred frequently in non-neurosurgical patients ${ }^{18}$ and that three patients $(20$ per cent) had ST and T wave changes in the recovery room. Breslow et al, also found that new ECG abnormalities occurred in 19 per cent of non-neurosurgical patients postoperatively. ${ }^{19}$ They speculated that these changes, which mostly involved the $\mathrm{T}$ wave, were not indicative of myocardial ischaemia, but of an unknown aetiology. The incidence of postoperative changes in our study (53 per cent) was considerably higher, suggesting the neurosurgical procedure as a strong aetiological factor. It is difficult to implicate induced hypotension since no ECG changes were observed during the period of hypotension.

Reiz has suggested that isoflurane anaesthesia produces coronary vasodilation which may result in myocardial ischaemia by means of a "coronary steal" in patients with coronary artery disease. ${ }^{20}$ More recently, other investigators have not been able to confirm these findings. ${ }^{21}$ In our study, three patients had clinical cardiac disease, but showed no ST segment changes intraoperatively. Postoperatively, two of these patients had transient nonspecific $T$ wave changes on their $E C G$, but no elevation of cardjac enzymes. The number of patients in this category is small, and thus no definitive conclusion on coronary steal can be drawn.

\section{Conclusion}

In summary, we conclude that ECG changes are relatively common intraoperatively in patients undergoing vascular neurosurgical procedures and even more common in the postoperative period. The aetiology of these changes remains unclear, but may be related to intracranial surgical manipulation. We found no enzymatic evidence of myocardial infraction during isoflurane-induced hypotension even in patients with clinical evidence of ischaemic heart disease. Although one should continue to be cautious and vigilant, we believe that isoflurane anaesthesia and isoflurane-induced hypotension can be safely employed to facilitate neurovascular surgery.

\section{Acknowledgments}

The authors wish to thank Dr. A.R. Henderson, Department of Biochemistry, for cardiac enzyme analysis, Mrs. R. Lok for Holter monitor analysis and Mrs. J. Butler for secretarial assistance.

\section{References}

1 Cropp GJ, Manning GW. Electrocardiographic changes simulating myocardial ischemia and infarction associated with spontaneous intracranial haemorrhage. Circulation $1960 ; 22: 25-38$.

2 Grande P, Christiansen C, Pedersen A, Christensen MS Optimal diagnosis in acute myoeardial infanction. A costeffectiveness study. Circulation 1980; 61: 723-8.

3 Samra SK, Kroll DA. Subarachnoid haemorrhage and intraoperative electrocardiographic changes simulating myocardial ischemia. Anesthesiologist's dilemma. Anesth Analg 1985; 64: 86-9.

4 White JC, Parker SD, Rogers MC. Preanacsthetic evaluation of a patienl with pathologic $Q$ waves following subarachnoid hacmorrhage. Anesthesiology 1985; 62: 351-4.

5 Byer E. Ashman $R$, Toth $L A$. Electrocardiograms with large, upright $T$ waves and long $Q-T$ intervals. Am Heart J 1947; 33: 796-806.

6. Weidler $D J$. Myocardial damage and cardiac arrhythmias after intracranial haemorrhage. A critical review. Stroke 1974; 5: 759-64.

7 Stober $T$, Kunze $K$. Electrocardiographic alterations in subarachnoid haemorrhage. J Neurol 1982; 227: 99-113.

8 Eisalo A, Peräsalo J, Halonen PI. Electrocardiographic abnomalities and some laboratory findings in patients with subarachnoid hacmorrhagc. Br Hcart J 1972; 34: 217-26.

9 Marion DW, Segal $R$, Thompson ME. Subarachnoid haemorrhage and the heart. Neurosurgery 1986; 18: 101-6.

10 Cruickshank JM, Neil-Dwyer G, Stoll AW. Possible role of catecholamines, corticosterojds, and potassium in production of electrocardiographic abnormalities associated with subarachnoid haemorrhage. Br Heart J 1974; 36: 697-706

11 Hunt $D$, McRae $C$, Zapf $P$. Electrocardiographic and serum enzyme changes in subarachnoid haemorrhage. Am Heart J 1969; 77: 479-88.

12 Fabinyi $G$, Hunt $D$, MCKinley $L$. Myocardial creatine kinase isoenzyme in serum after subarachnoid haemorrhage J Neurol Neurosurg Psychiatry 1977; 40: 818-20.

13 Kaste M, Somer H, Konttinen A. Heart type creatine kinase isoenzyme (CK MB) in acute cerebral disorders. $\mathrm{Br}$ Heart J 1978; 40: 802-5.

14 Rudehill A. Gordon E. Sundqvist K, Sylven C, Wahtgren NG. A study of ECG abnormalities and myocardial specific enzymes in patjents with subarachnoid haemorrhage. Acta Anaesthesiol Scand 1982; 26: 344-50.

15 Pool JL. Vasocardiac effects of the circle of Willis. Arch Neurol Psychiatry 1957; 78: 355-68.

16 Hammer WJ, Luessenhop AJ, Weintraub AM. Observations on the electrocardiographic changes associated with subarachnoid haemorrhage with special reference to their genesis. Am J Med 1975; 59: 427-33. 
17 Lachman AB, Semler HJ, Gustafsan RH. Postural ST-T wave changes in the radioelectrocardiogram simulating myocardial ischemia. Circulation 1965; 31: 557-63.

18 Griffin RM, Phipps JA, Evans JM. Electrocardiographical changes in the perioperative period. A pilot study. Anaesthesia 1985; 40; 193-7.

19 Breslow MJ, Miller CF, Parker SD. Walman AT, Rogers $M C$. Changes in T-wave morphology following anaesthesia and surgery: a common recovery-room phenomenon. Anesthesiology 1986; 64: 398-402.

20 Reiz S, Balfors E, Sorensen MB, Ariala S, Friedman A, Truedsson $H$. Isofurane - a powerful coronary vasodilator in patients with coronary artery disease. Anesthesiology 1983; 59: 91-7.

21 Merin $R G$, Lowenstein E, Gelman $S$. Is anesthesia beneficial for the ischemic heart? III. Anesthesiology 1986; 64: 137-40.

\section{Résumé}

Nous avons évalué, à l'aide d'un monitorage électracardiographique et de mesures d'enzyme cardiaque sériées, les effers de l'anesthésia à l' isoflurane et de l'hypotension induite chez 33 patients neurochirurgicaur. Nous avons obtenu un électrocardiogramme (ECG) et des enzymes sériques en période préopératoire, en période intraopératoire et en période pastopératoire dans la salle de réveil et durant trois jours consécutifs. Les dérivations $I I, V_{1}$ et $V_{g}$ de I"ECG ont élé monitorées de façon continue durant l'anesthésie. L'incidence d'ECG préopératoire ararmale (42 pour cent) était élevée chez les patients ayam en une hémorrhagie sous-rachidienne. II s'est formé des changements d'ECG. en période insraopératoire, chez dix patients. mais ces changements n'étaient pas reliés a l'hyposension induite par isofturane. Un ECG anormal s'est manifesté en période postopératoire chez 53 pour cent des patients. Ces anomalies étaient surtout composées de changements non spécifiques du segment ST ou de l'onde T. L'activité d' enzyme cardiaque ne s'est élevée à oucun moment. Nous avons trouvé que des changements non spécifiques dans le ECG sont rela. tivement fréquents chez les patien's subissant une neurochirurgie vasculaire. II $n^{\prime}$ y avait pas d' évidence enzymatique d" infarclus du myocarde et nous ne pouvons que spéculer que ces changements dans le ECG sont retiés da la maniputation chinurgicale intracrânienne. 